\title{
Contemporary anti-Colonial Self-Determination Claims AND THE DECOLONISATION OF INTERNATIONAL LAW
}

\author{
Amy Maguire*
}

The most prominent engagement of self-determination was in the decolonisation era, when the right facilitated the emergence to independence of formerly colonised 'peoples'. The newly decolonised states met the 'salt-water' test of colonialism. Some contemporary commentators argue that self-determination's mission of decolonisation is now complete. Self-determination is less frequently asserted today; however, contemporary 'hard cases' remain. Some of these cases involve peoples who can demonstrate a continuing colonial experience. For varying reasons, these claimants do not pass the 'salt-water' colonial test, and their claims have not adequately been addressed by the international community. Instead, claimant groups are abandoned to the political whims of their administering states. This article examines the significance of the colonial experience for two contemporary claimant peoples; Indigenous peoples in Australia and Irish nationalists in the North of Ireland. Data gathered through qualitative research interviews, and analysed according to a grounded theory approach, demonstrate that the selfdetermination claims of these peoples are stifled by the denial of their contemporary colonial experiences. The current failure of international law to consider these claims through a colonial lens is inhibitive of creative self-determination solutions in multi-ethnic states. Self-determination, as a universal human right, retains the potential to meet the needs of these contemporary, anti-colonial claimants. In this article, I demonstrate how international legal approaches to self-determination may be decolonised in order to facilitate the full and fair evaluation of contemporary anti-colonial claims.

The right of self-determination was deeply engaged in the process of decolonisation, which peaked in the 1960s and 1970s. In the twenty-first century, some have argued that self-determination's mission of decolonisation is almost or entirely complete. ${ }^{1}$ Contemporary selfdetermination claimants who assert a colonial experience, but do not meet the archaic 'salt-water' test ${ }^{2}$ of colonialism, have been marginalised in

Lecturer, Newcastle Law School, Australia.

See, for example, Hannum (1993-94), p 31; Pearson (2006), p 28.

The 'salt-water' test of colonialism required a colonial territory and people to be geographically and ethnically distinct from the colonising power. Contemporary commentators have condemned this test as unjust and indefensible in the twenty-first century. See: Hurrell (2003), p 292; Wippman (1998), p 11. 
international legal discourse. Their circumstances are seen to raise internal political issues, to be dealt with by the relevant administering state.

This article is concerned with the circumstances of contemporary selfdetermination claimants, who continue to experience colonialism but are unable to pass the 'salt-water' test. During the imperial age, European powers acquired colonial territories in Africa, Asia, the Americas and the Pacific, which they claimed as evidence of their prestige and superior civilisation. ${ }^{3}$ According to the salt-water test, a 'colony' could only be defined as such if it was a territory separated from the imperial power by geographical and cultural distance.

In the $1960 \mathrm{~s}$, as the decolonisation movement took hold, powerful states continued to resist the challenges to the foundations of the international order that at that time were gaining momentum around the globe. The salt-water test was used to ensure normative predictability in the new flood of self-determination claims. ${ }^{4}$ Contemporary legal commentators have recognised that this test, which aimed to impose predictability by ruling out claims from peoples not separated by an ocean from their colonisers, was manifestly unjust. ${ }^{5}$ Ethnic and other minority groups living in 'settler' colonies $^{6}$ could not conform to the salt-water test. Persistent commitment to the salt-water test has marginalised such groups, some of whom continue to experience forms of colonial domination within established nation-states. ${ }^{7}$ By entrenching the authority of the state over minority groups living within its borders, the salt-water test prevents minority peoples from operating in the international legal forum. ${ }^{8}$ As such peoples well recognise, salt-water colonialism is not the only form of domination, and for this reason the saltwater test remains indefensible. ${ }^{9}$

In the first part of this article, I briefly discuss the nature and scope of self-determination, a collective right central to the entire framework of human rights law. This discussion provides a doctrinal framework for my qualitative data, which were gathered through research interviews with targeted participants from two case study groups. In the following section, I explain my choice of case studies and my use of grounded theory methodology. Taking an interpretivist approach to qualitative data has facilitated my evaluation of self-determination claims in the context of the contemporary colonial experience. I then consider the experiences of

Anghie (2004), pp 64-65.

Hurrell (2003), p 292.

Hurrell (2003), p 292.

6 Such colonies are distinct from the 'salt-water' cases, in that the colonising power transported a settler community to the territory. The settlers, their descendants and other migrants have since established independent nation-states.

Ritchie (2005).

Anaya (1996), p 43.

Wippman (1998), p 11. 
Indigenous peoples in Australia, ${ }^{10}$ and Irish nationalists in Northern Ireland, ${ }^{11}$ to demonstrate the stifling impact of colonialism on some contemporary self-determination claimant groups. Comparison of the circumstances of these two claimant groups, both situated in settler colonial territories, illuminates the adaptable nature of self-determination and challenges the position that self-determination necessarily threatens state sovereignty. I go on to propose means by which the international law on self-determination may itself be decolonised, in order to enable the fair evaluation of contemporary, anti-colonial self-determination claims. International law is challenged to move beyond its focus on ending a particular type of European colonialism, and develop nuanced approaches to the diverse self-determination claims made by Indigenous peoples, nationalist groups and others. ${ }^{12}$

\section{The Right of Self-determination}

The right of self-determination is protected by common Article 1 of the International Covenant on Civil and Political Rights (ICCPR) and the International Covenant on Economic, Social and Cultural Rights (ICESCR):

1 All peoples have the right of self-determination. By virtue of that right they freely determine their political status and freely pursue their economic, social and cultural development. ${ }^{13}$

Self-determination is essential to the human rights framework, as demonstrated by its centrality in these two key documents of international

10 In this article, I use the term 'Indigenous peoples' in relation to Aboriginal and Torres Strait Islander peoples in Australia. 'Indigenous Peoples' is the term commonly used in international legal commentary, and reflects the titles of the key Indigenous-specific structures such as the Declaration on the Rights of Indigenous Peoples and the United Nations Permanent Forum on Indigenous Issues. I acknowledge that there are numerous and diverse Aboriginal and Torres Strait Islander peoples who are indigenous to Australia. The term 'peoples' connotes their distinct status as First Peoples, which is significant for Indigenous claims to self-determination under international law.

'Northern Ireland' is the official term for the north-eastern six counties of the island of Ireland, which is administered as a province of the United Kingdom of Great Britain and Northern Ireland. The term 'Northern Ireland' is often rejected by Irish nationalists living in that territory, in favour of terms such as 'the North of Ireland' or 'the Six Counties'. In this article, I use the terms 'Northern Ireland' and 'the North of Ireland' interchangeably, in order to acknowledge the competing nationalist identifications of the two main communities: Irish nationalists and British unionists.

13 International Covenant on Civil and Political Rights, opened for signature 16 December 1966, 999 UNTS 171 (entered into force 23 March 1976), International Covenant on Economic, Social and Cultural Rights, opened for signature 16 December 1966, 999 UNTS 3 (entered into force 3 January 1976) 
human rights law. The phrase 'all peoples' demonstrates that the right is universal in its application. ${ }^{14}$

Self-determination entails the right of a 'people' to choose their own form of political organisation and relationship to other groups. ${ }^{15}$ However, self-determination goes beyond this 'essence' of political control, to extend 'full rights in the cultural, economic and political spheres'. ${ }^{16}$ The right represents the means for a people 'to preserve its cultural, ethnic, historical, or territorial identity'. ${ }^{17}$ Indeed, the economic, social, cultural and political dimensions of self-determination are interlinked. ${ }^{18}$ Therefore, selfdetermination has significance far beyond the issues of state territory and sovereignty, and assertions of the right may or may not include claims to independent statehood.

Self-determination is a process, rather than any single outcome of that process. ${ }^{19}$ Indeed, self-determination may be described as a right with many 'faces', several of which have been identified by Kirgis. These include freedom from colonialism, secession, reunification of formerly divided states, limited autonomy within the state, protection as a minority group and choice of form of government. ${ }^{20}$ Each people exercising self-determination must shape the manifestation of the right in their particular circumstances. All peoples may continue to aspire to a greater degree of self-determination in the future, whether through changes to borders, changes to governments or changes to social and economic circumstances.

Self-determination is not solely concerned with decolonisation. Expressions of self-determination over the past five decades demonstrate a wide variety of motivating circumstances, many of which were not explicitly colonial. Independence has been achieved by peoples whose struggles were secessionist rather than de-colonialist - for example, in Singapore (1965) and Bangladesh (1971). ${ }^{21}$ The international community has recognised the validity of the self-determination claims of peoples in Namibia, East Timor and Palestine, none of which complied with the salt-water colonial test. ${ }^{22}$

14 For example, see: Importance of the Universal Realisation of the Right of Peoples to SelfDetermination and of the Speedy Granting of Independence to Colonial Countries and Peoples for the Effective Guarantee and Observance of Human Rights, GA Resolution 3382 (XXX) (1975)

15 Brownlie (2003), p 553.

16 Thornberry (1989), p 880.

17 Daes (1993), pp 4-5.

18 Dixon and McCorquodale (2003), p 226.

19 Pomerance (1982) cited in Nettheim (1988), p 119.

$20 \quad$ Kirgis (1994), p 307.

$21 \quad$ Berman (1988-89), p 86.

22 Dixon and McCorquodale (2003), p 226. The right to independence of Namibia was confirmed by the Security in a 1978 resolution, and several subsequent resolutions, prior to Namibia's achievement of independent statehood in 1990: Independence of Namibia, SC Res 435, 33 UN SCOR, 2087th mtg, UN Doc S/12865 (1978). The Security Council first acknowledged the right of East Timor to independence through a resolution in 1975, 
The reunification of East and West Germany was also defined as an exercise of self-determination by four of five permanent members of the UN Security Council, via treaty, in $1990 .{ }^{23}$ There was no suggestion that the German reunification could be primarily attributed to the decolonisation movement. In 2007, the United Nations recognised that independent statehood was the most viable option for the future of Kosovo, ${ }^{24}$ which duly declared independence from Serbia in 2008. Many states have since supported Kosovar self-determination, and recognised Kosovo as an independent state, ${ }^{25}$ despite the fact that it is not a colonial case.

Therefore, as Robert McCorquodale confirms:

The right of self-determination applies to all situations where peoples are subject to oppression, subjugation, domination and exploitation by others. It is applicable to all territories, colonial or not, and all peoples. ${ }^{26}$

My concern in this article is to highlight the position of claimant peoples whose contemporary experience remains influenced by colonialism. In light of suggestions that the decolonising mission of self-determination is complete, and evidence that the right is being more frequently asserted outside the colonial context, it is crucial that contemporary anti-colonial 'hard cases' are not left behind in international legal analysis.

\section{Methodology}

This article draws on a combination of doctrinal legal research and qualitative socio-legal research, with particular emphasis on data gathered through indepth research interviews with fourteen participants in Ireland and fourteen in Australia. In his general international law text, Antonio Cassese advocates combining doctrinal legal research with a sociological approach:

I believe that it is misleading to consider international law as a piece of reality cut off from its historical, political, and ideological context. To grasp international law in all its ramifications, one ought to look at it as a set of continuously changing elements of a whole. ${ }^{27}$

and has maintained a role in its emergence to independent statehood: Resolution on East Timorese Self-Determination, SC Res 384, 1869th mtg (1975). Although Palestine has not achieved independent statehood, its right to independence is recognised by the international community, notably through its Permanent Observer Mission to the United Nations.

Treaty on the Final Settlement With Respect to Germany, 29 ILM 1187 (signed 12 September 1990)

Comprehensive Proposal for the Kosovo Status Settlement, United Nations Mission in Kosovo, 2 February 2007. 
Taking a socio-legal approach to the problem identified in this article sheds light on the current state of the law, and reveals means by which the law could more effectively promote the realisation of self-determination by claimant peoples.

Qualitative research interviews enabled me to explore the contemporary colonial experiences of self-determination claimants, and analyse these from an interpretivist perspective. That is, I have sought to understand the concept of self-determination in the context of its specific operation for contemporary claimants. ${ }^{28}$ Analyses of self-determination typically have been highly doctrinal; in this article, I privilege the experiences and aspirations of rights claimants to highlight a significant gap in the protection provided by the legal right of self-determination. In other words, I use the voices of rights claimants to 'talk back' to international law.

Research participants in this study were targeted due to their experiences and expertise in self-determination, ensuring that all participants approached the research project from an informed position and delivered 'information-rich' data through the interviews. ${ }^{29}$ Twenty-five of the 28 participants identified themselves as self-determination claimants, while the other three were academic or professional experts in self-determination. ${ }^{30}$ Each of the participants spoke to me solely on their own behalf, rather than as representatives of a community position. However, the depth and quality of the perspectives offered challenge the dominant narrative of the international law on self-determination. ${ }^{31}$ Qualitative research does not seek to make claims of generality, ${ }^{32}$ but rather to show valid and reliable connections between data and analysis. ${ }^{33}$

In this section, I explain my choice of case studies, and my use of grounded theory method in the analysis of the interview data. This provides the background for a later section that sets out the perspectives of rights claimants on the meaning of self-determination, and the ways in which their contemporary colonial experiences have stifled their capacities to claim that right.

\section{Case Studies in This Article}

In this article, I consider two case studies: Irish nationalists in the North of Ireland and Indigenous peoples in Australia. These two cases are vastly different in terms of location, culture, language, historical experience and demographics. Indeed, the two claimant groups diverge significantly in terms of the form of self-determination they typically claim. One reason for this is that there is a much larger degree of homogeneity of experience and

\footnotetext{
$28 \quad$ Lin (1998), p 162.

$29 \quad$ Baxter and Eyles (1997), p 513.

30 Participants were members of one of five groups: lawyers, academics, politicians, human rights activists and community workers.

31 Hughes (2006).

$32 \quad$ Lin (1998), p 163.

33 Baxter and Eyles (1997), p 512.
} 
culture among Irish nationalists in the small territory of Northern Ireland than there is among Indigenous peoples in Australia, who are dispersed across a massive land-mass in both remote and urban areas. Irish nationalists claim self-determination in the form of a united Ireland, requiring the separation of Northern Ireland from the United Kingdom. Indigenous peoples in Australia have generally sought self-determination solutions within the framework of the existing Australian state. ${ }^{34}$ As Linda Burney explains, Indigenous peoples have not surrendered their claims to sovereignty; however, the diverse Aboriginal and Torres Strait Islander communities do not make a claim 'to the whole of Australia'. ${ }^{35}$

This distinction between the two case studies is helpful in terms of this research, as it enables me to consider a range of possible self-determination solutions. Consideration of different types of self-determination claims illuminates the adaptable nature of the right, and challenges the typical statist view that self-determination necessarily entails a claim to secession and a challenge to a state's territorial integrity.

However, the two case studies also share an important similarity. Irish nationalist and Indigenous Australian self-determination claims are heavily influenced by a colonial experience that has not been adequately recognised at the domestic or international levels. Irish nationalists in the North of Ireland and Indigenous peoples in Australia claim a continued experience of 'settler colonialism'. ${ }^{36}$ This experience is distinct from the 'salt-water' colonialism experienced by the many nation-states formed after World War II, whose claims to self-determination were upheld by international law through the project of decolonisation. This shared experience of settler colonialism, and its contemporary effects, provide the central focus of this article.

I acknowledge that British unionist people in Northern Ireland, and in the United Kingdom, are entitled to exercise self-determination. Similarly, the whole of the people of Australia are engaged in the exercise of selfdetermination, through the Australian nation state ${ }^{37}$ In this article, however, I do not explore the right of the British or Australian peoples to self-

34 None of the interview participants, and very few other Indigenous commentators, propose self-determination solutions involving the establishment of a separate Indigenous state. An exception is Michael Mansell, National Secretary of the Aboriginal Provisional Government. This association has claimed over 1000 members around Australia, however, it is not a prominent movement and there is little evidence of recent activity. It advocates the establishment of a sovereign state for Aborigines, located on Crown land throughout Australia, and the right of communities to determine the laws applying to them on their country. See Aboriginal Provisional Government (1990). Mansell argues that Australia could recognise an Aboriginal nation, in a manner similar to the special status of Norfolk Island: Mansell (2005), p 82.

35 Burney (2006).

36 See Clayton (1996).

37 Although, of course, this structure provides greater capacity to some than to others in terms of decision-making, contributions to the political process, and socio-economic inclusion. 
determination alongside the self-determination claims of Irish nationalists and Indigenous peoples in Australia. The rights to self-determination of Irish nationalists and Indigenous peoples have been suppressed and undermined through the colonial process in such a way that their contemporary claims call for particular attention.

\section{Grounded Theory Approach}

Grounded theory has been defined as the 'discovery of theory from data'.$^{38}$ Grounded theory research methods are appropriate where the researcher wishes to 'make knowledge claims about how individuals interpret reality'. ${ }^{39}$ This approach to research relies on a process of constant comparison, whereby data and emerging analysis are constantly compared to generate a theory. ${ }^{40}$ In maintaining a constant focus on the data gathered through qualitative research methods, the researcher identifies links between concepts. ${ }^{41}$ Using the technique of constant comparison, grounded theory researchers can lift data beyond its basic meanings to develop abstract theoretical conclusions. ${ }^{42}$ Grounded theory is not designed to test previously developed hypotheses; rather, theoretical conclusions emerge through deep analysis of data. ${ }^{43}$ Grounded theory research should produce a "central variable' that 'will serve as the backbone of a researcher's "story", ${ }^{44}$

In the research on which this article is based, I grounded my findings in the meanings expressed by interview participants by using the constant comparison method, coding frequently raised concepts and using direct quotations from transcripts. Quotes are useful 'low inference descriptors', ${ }^{45}$ which assist in the accurate reporting of participants' perspectives. I have used the data analysis software NVivo to categorise data. This enabled me to identify hierarchies of 'concepts' or meanings expressed by research participants, and to discern relationships between concepts. Later in this article, I explore one set of related concepts, to propose means by which the international law of self-determination may be decolonised.

Here, I focus on the theme that emerged from data analysis as the 'core variable': the contemporary colonial experience of the case study groups and the influence of that experience on self-determination claims. The core variable recurs frequently throughout the data, links various pieces of data, becomes more detailed through constant comparison, and has significance in theory-generation. ${ }^{46}$ The core variable of colonialism, as discussed by

\footnotetext{
Glaser and Strauss (1967), p 1.

Suddaby (2006), p 634.

Glaser and Strauss (1967), p 104.

Harry et al (2005), p 5.

Suddaby (2006), p 636.

Suddaby (2006), p 636.

LaRossa (2006), p 838.

Johnson (1997), p 283.

Byrne (2001), p 1155.
} 
interview participants, drew together the other themes raised in interviews 'to form an explanatory whole'. ${ }^{47}$

In the following section, I explore participants' understandings of selfdetermination, and their perceptions of how a contemporary colonial experience impacts upon their claims to self-determination. Analysis of these perspectives was instrumental in generating the proposals I make later in the article, regarding the decolonisation of the international legal approach to self-determination.

\section{Contemporary Claimants' Perceptions of Self-determination and the Contemporary Colonial Experience}

Self-determination is an essential element in the international human rights framework. Over the past century, self-determination has been called upon as a 'concept of liberation'. ${ }^{48}$ The right has an ongoing character, and may adapt according to the needs of a given people. Indeed, it is a right with many 'faces', including freedom from colonialism, secession, reunification of formerly divided states, limited autonomy within the state, protection as a minority group and choice of form of government. ${ }^{49}$ As noted above, it is for each people asserting self-determination to shape the right's realisation in their particular context. This is certainly the case for contemporary claimant groups, whose aspirations for self-determination need to translate to the realities of life in multi-ethnic states.

\section{The Meaning of Self-determination from Irish Nationalist Perspectives}

The starting point for qualitative research interviews conducted with participants in Ireland was the international legal definition of selfdetermination. All fourteen participants accepted that definition as a starting point, and each then went on to apply the definition in practical terms. In this section, I consider some of their perspectives on the meaning of selfdetermination. The Irish interview participants embraced the idea of selfdetermination as a right operating on a range of levels.

Bríd Rodgers reflected on the independence aspect of selfdetermination, stating that it is 'the right of a people to decide their own political structures and political destiny, not to have it imposed on them by an outside force'. Rodgers went on to note the complicating aspect of this conception of the right in the Irish context:

The issue [in Ireland] is that there are two sets of people on the island who see self-determination differently. The only way to solve that is to get to a context where you accept the legitimacy of both, but you

Strauss and Corbin (1998), p 146.

Thornberry (1989), p 867.

Kirgis (1994), p 307. 
provide a context where they can work together, and eventually heal, and move on to self-determination. ${ }^{50}$

Here, Rodgers provides an interesting starting point for a contemporary selfdetermination inquiry, by acknowledging that all peoples on the island of Ireland, nationalist or otherwise, are entitled to be part of any future selfdetermination solution. Paul O'Connor agreed that the entire people of the island are entitled to decide their destiny together. ${ }^{51}$

To Eoin Ó Broin, self-determination operates on three levels: the nation, the community and the individual. Along with balancing these three 'sites' of self-determination, he argued that the right must also be balanced with social, economic, political and cultural rights. ${ }^{52}$ Both Paul O'Connor and Terry Enright emphasised the importance of social and cultural freedom as aspects of self-determination. ${ }^{53}$ Speaking from an academic perspective, Robert McCorquodale recognised that a number of self-determination matters in recent times had been dealt with on an economic or cultural level, rather than as purely political issues. ${ }^{54}$

Essential to this multi-faceted conception of self-determination is the notion of inclusion in governance. Anthony Coughlan acknowledged that self-determination had traditionally been understood to refer to independent statehood:

but it also refers to the state you're in, and whether it respects your culture and language, and right to a ... standard of living, access to jobs, freedom from discrimination. ${ }^{55}$

This perspective highlights the issue raised by Rodgers: that groups other than Irish nationalists must be included in the development of future selfdetermination solutions. In this context, Ó Broin noted the disadvantaged status of the small Irish Traveller community. The circumstances of this group tend to be marginalised in the political conflict between Irish nationalists and British unionists; however, Travellers would need to be included in any future Irish self-determination solution. ${ }^{56}$

Another common theme among participants was that self-determination has to be interpreted on a community level if it is to mean anything to claimants. According to Margaret Ward:

I think it has to start with people's lived reality - what difference will it make to their lives? If they can't be convinced on that then that

Rodgers (2006).

O'Connor (2006).

Ó Broin (2006).

O’Connor (2006); Enright (2006).

McCorquodale (2006).

Coughlan (2006).

56 Ó Broin (2006). Irish Travellers are a semi-nomadic community of Irish ethnic origin. 
kind of high level of objective [the concept of self-determination] wouldn't move them. ${ }^{57}$

Eoin Ó Broin also emphasised the community aspect of selfdetermination, arguing that the right must be concerned primarily with community-based activism, empowerment and engagement on issues affecting people in their everyday lives. ${ }^{58}$ Niall Murphy provided an example of community engagement with self-determination through the Gaelic Athletic Association, which he described as a custodian of Irish cultural pursuits.

\section{The Meaning of Self-determination from the Perspectives of Indigenous Peoples in Australia}

Research interviews with Indigenous participants in Australia also began with a discussion of the international legal definition of self-determination. All fourteen participants engaged with the basic concept of selfdetermination, and each proceeded to apply the right in their particular context. Notions of independence, autonomy and equality were stressed by participants in their engagement with the right.

In exploring the meaning of self-determination, Irabinna Rigney asserted that the right 'is for the members of a group to determine' ${ }^{59}$ Mick Dodson agreed that the form that self-determination might take in a particular case is secondary to the consideration of whether claimant people are empowered to express the right as they wish. ${ }^{60}$ Irene Watson also emphasised the importance of translating the universal definition of selfdetermination into Indigenous-specific contexts. Watson regarded the international legal definition of the right as 'a useful tool to assert a place from which such groups can begin in asserting their different identities'. ${ }^{61}$

One unifying factor identified by Rigney in terms of self-determination for groups of Indigenous peoples in Australia was the importance attached to 'the right for Indigenous peoples to be Indigenous':

The right to be Indigenous is the right to practise, uphold, maintain, revive, reaffirm the rights of Indigenous cultures and languages to exist in Indigenous peoples into the future. ${ }^{62}$

Allied to this concept is Linda Burney's argument that self-determination must entail recognition of the status of Aboriginal and Torres Strait Islander peoples as First Peoples, and acknowledgment of their survival in the face of dispossession and colonial domination. ${ }^{63}$

\footnotetext{
Ward (2006).

Ó Broin (2006)

Rigney (2006).

Dodson (2006).

Watson (2006).

Rigney (2006).

Burney (2006).
} 
While participants emphasised the importance of equality for Indigenous and non-Indigenous peoples in Australia, some distinguished equality from 'sameness'. Self-determination for Indigenous peoples in Australia ought not to be seen as the entitlement to the same sorts of lives and cultural practices as other peoples in Australia - that is, a form of 'formal' equality. Rather, Indigenous self-determination requires an ongoing commitment to ensuring that Aboriginal and Torres Strait Islander communities may protect their distinctiveness, and so move towards the achievement of substantive equality. ${ }^{64}$

Irabinna Rigney proposed a range of means by which selfdetermination and substantive equality might be achieved, including the rights of Indigenous people:

To be educated in their own languages in their schools, to have access to their own laws, to have access and rights to their own land and freedom of movement without restriction, to have the freedom to be represented by a voting representative of their people in an elected body, they should be attached and inserted into the dominant Australian economy ... ${ }^{65}$

Other factors central to self-determination include the need to provide a space in which Aboriginal law might function ${ }^{66}$ the right to be consulted and to give or withhold free, prior and informed consent to decisions that will affect Indigenous people, ${ }^{67}$ the requirement for a settlement - whether through a treaty or other agreement - between Indigenous peoples and the Australian government, ${ }^{68}$ and recognition of the fundamental significance of the connection between Indigenous self-determination and land. ${ }^{69}$

One key aspect of Indigenous self-determination, emphasised by Irabinna Rigney and Paul Hughes, is the importance of education that reflects Aboriginal and Torres Strait Islander cultures and languages. This was also significant for Irish nationalist interview participants. ${ }^{70}$ Hughes argued that the identity of Indigenous children can be destroyed by education that fails to teach them 'who they are'. ${ }^{71}$ In this context, John Maynard reflected on his own experience of schooling during the 1960s. He remembered being taught post-contact 'British history', which offered nothing with which an Aboriginal student could identify; Indigenous people were represented either as "wild savages' or 'good' blackfellas, like Jacky Jacky. ${ }^{72}$

\footnotetext{
64 Ridgeway (2006); Rigney (2006).

65 Rigney (2006).

66 Watson (2006).

67 Behrendt (2006); Calma (2006); Dodson (2006).

68 Dodson (2006).

69 Burney (2006).

70 Murphy (2006); Enright (2006); O’Connor (2006).

71 Hughes (2006).

72 Maynard (2006). Jacky Jacky was an Aboriginal guide who accompanied the surveyor Edmund Kennedy on an expedition to Cape York. Kennedy was killed; however, Jacky
} 
Some Indigenous participants also reflected on the more individualistic aspect of self-determination. For example, Mick Mundine commented that 'self-determination is within yourself - being proud of who you are. Aboriginal people find that really hard because you have all these people knocking you down all the time. ${ }^{73}$ This reflection relates to the comments of Hughes and Rigney regarding culturally sensitive education, in that each respondent emphasised the significance of self-awareness, self-esteem and pride - all values that have been undermined by Indigenous peoples' experience of paternalism and colonialism. ${ }^{74}$

\section{The Contemporary Colonial Experience}

Colonialism is a phenomenon with political, social, geographical, cultural and economic dimensions. It defies simple definition, but historically has involved the domination of a people by a foreign metropolitan power, often accompanied by the transfer of metropolitan settlers. ${ }^{75}$ The term "postcolonial' can be taken to refer to societies established through colonialism. Some such societies remain subject to what has been called 'neo-colonial' domination, whether through the rise of new elites following the establishment of an independent state, discrimination based on race, language or religion, or the unequal treatment of minorities, including Indigenous peoples. ${ }^{76}$ Through colonial expansion, European colonial powers spread an international law 'imbued with European values'. ${ }^{77}$ In the twenty-first century, when most colonial territories have attained formal 'freedom', this European hegemony in international affairs has been transferred to the few dominant powers that hold permanent seats on the UN Security Council. ${ }^{78}$

Some international legal scholars have, in recent decades, reminded the international legal community that the mission of decolonisation has not come to an end. For example, Gerry Simpson argues that the end of the socalled Age of Empire merely reveals most states to be somehow imperial. ${ }^{79}$ This view supports the finding of the UN Rapporteur on self-determination, Héctor Gros-Espiell, that the notion of colonialism is far broader than the typical understanding of colonial domination characterised by the salt-water test. $^{80}$ As Kwame Nkrumah famously argued, contemporary forms of

Jacky was lauded by the establishment as a loyal and devoted guide. His name later became used in the pejorative sense, to denote an Aboriginal person who collaborated in the white mission to oppress Aborigines. See, for example, Mansell (2003).

73 Mundine and Valilis (2006).

74 Hughes (2006); Mundine and Valilis (2006).

$75 \quad$ Ryan and Mullen (1998), p 225.

Ashcroft et al (1995), p 2.

Triggs (2006), p 11.

Matua (2000), pp 34, 37.

Simpson (1996), p 255.

Gros Espiell (1980), [40]. 
colonialism - often termed 'neo-colonialism' - can be more difficult to detect and more insidious than past overt forms. ${ }^{81}$ International legal analyses must remain conscious of these insightful perspectives in order to avoid the trap described by Anghie - that is, reproducing colonialism by failing to recognise its continued influence. ${ }^{82}$

There is a vast literature on colonialism and the process of decolonisation, which I do not present here because it has been thoroughly explored elsewhere. ${ }^{83}$ Colonialism may today be identified by the type of administration present in a society, rather than distance, as was the case in the antiquated salt-water test. ${ }^{84}$ The people best placed to identify colonialism are those who experience its effects. ${ }^{85}$ In that context, I now turn to contemporary perspectives on the colonial experience from Irish nationalists in the North of Ireland and Indigenous peoples in Australia.

\section{Contemporary Manifestations of Colonialism in Ireland}

Britain has maintained some presence on the island of Ireland for over 800 years. Owing to Britain's international standing as a military and political power, debate on whether contemporary circumstances in the North of Ireland constitute a form of colonialism has been almost entirely stifled. However, some commentators have continued to recognise that Irish nationalists maintain a struggle against colonialism or neo-colonialism. ${ }^{86} \mathrm{In}$ thirteen of the fourteen in-depth interviews conducted in Ireland for this research, participants recognised a continued and explicit colonial British influence in the North ${ }^{87}$ Participants tended to focus on three aspects of the colonial experience: the nature of British administration in Northern Ireland; social imperialism and the colonial mindset; and the suppression of Irish culture.

In arguing that colonialism relates not to distance but to type of administration, McCorquodale asked: 'Is the type of administration a foreign administration over those who are different and who don't share the same approach? ${ }^{88}$ The use of the term 'foreign' is complicated in the Northern Irish context because over half of the constituents of that jurisdiction identify themselves as British or 'Northern Irish' or 'Ulstermen', and remain accepting of British governance. For Irish nationalists, however, British rule is both foreign and different in approach from how they imagine governance

\footnotetext{
$81 \quad$ Nkrumah (1965).

$82 \quad$ Anghie (2004), pp 312-13.

83 See, for example, van Arkel et al (1982); Ashcroft et al (2000); Coombes (2006); Loomba (2005); Sartre (1964).

$84 \quad$ McCorquodale (2006).

85 See Jean-Paul Sartre, Preface, in Fanon (1965), p 12.

86 Enright (2006); Kolodner (1994-95), p 157; Swan (1986).

87 Respondent Christine Bell also identified a colonial legacy, but concluded that the colonial analysis was not particularly helpful in the contemporary context: Bell (2005). 
would take shape were Ireland unified, as was made clear by interviewees in this research.

Like McCorquodale, Bernadette McAliskey rejected the salt-water approach to colonial categorisation, finding that the British presence in Ireland has never been appropriately named as colonial, due to the erroneous perception that colonies must be distant from the imperial power. ${ }^{89}$ Further, several participants in this study identified the unaccountability of the British ruling class as a key signifier of continued colonialism. Anthony Coughlan stated: 'The classic characterisation of colonialism was a subordinate people who had their laws made by others, by foreigners, and Britain does still do that in Northern Ireland. ${ }^{90}$ Terry Enright was far more explicit in his condemnation of the unaccountable and distant ruling class of British politicians and bureaucrats primarily responsible for the governance of Northern Ireland:

Those people are like a secret society, behind closed doors, who still think of us as the natives and still think that the natives have to be told how to live and what to do. ${ }^{91}$

For Irish nationalists, self-determination would require accountable and representative governance, rather than continued dominance by the world's greatest-ever imperial power.

Notwithstanding the recent devolution of some powers to a powersharing government in Belfast, another vestige of colonialism complained about by some participants in this study is social imperialism. Northern Ireland as a quasi-state was constructed for the benefit of its British unionist population, who for most of its history have been dominant in a broad range of social fields. ${ }^{92}$ Eoin Ó Broin argued that the legacy of unionist dominance in the North of Ireland has been the creation of a class of people who 'benefited from the dividends of imperialism', from the most powerful politicians and professionals to the workers able to gain reliable employment in the shipyards and factories. ${ }^{93}$ Meanwhile, Irish nationalists in the North have suffered marginalisation and discrimination in all fields of social life. ${ }^{94}$

Paul O'Connor developed this argument further, finding that antiCatholic sentiment and sectarian conflict has been used as a justifying ideology for British imperialism in Ireland. O'Connor perceived a legacy of the superiority of one group over another as a continuing symptom of colonialism:

You cannot take people out of their homes, kill them, starve them, treat them like shit, for centuries, unless you had something in your

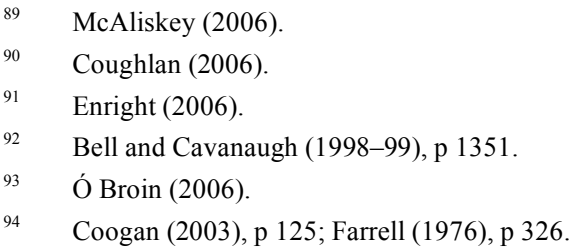


head which told you that they were somehow less than you. You used religion to do it here, and you use race elsewhere. ${ }^{95}$

It is clear from such perspectives of the colonised that, whatever future political settlements might be made, self-determination in Ireland must be asserted on the basis that all the people of the island have equal entitlements to rights and recognition.

A further aspect of continued colonial influence identified by Irish participants in this study was the dominance of British culture over Irish culture within many areas of social life. An example identified by Paul O'Connor was the use of British points of reference, such as visiting Big Ben, in the textbooks used by children in schools. For O'Connor's children, the famous sites of London have no cultural relevance, ${ }^{96}$ and they would be better served by education that reflects their Irish identity. As was recognised by Niall Murphy, some of the key areas in which Irish people throughout Ireland assert self-determination lie within the cultural sphere. In promoting the use of the Irish language, and supporting Gaelic sports, people claim their cultural identity. ${ }^{97}$ Often, though, the British administration either fails to support or actively discourages the practice of Irish culture. ${ }^{98}$ The suppression of Irish culture reflects and reinforces the continued influence of colonialism, and particularly the notion of the superiority of the colonial culture over the culture of the colonised.

Sinn Féin member of the Northern Ireland Assembly, Martina Anderson, explicitly identified Irish nationalism as a struggle against colonialism. Anderson asserted that this struggle was shared with other peoples experiencing colonialism in the present. $^{99}$ Indigenous research participants in Australia also expressed this sense of solidarity with the peoples of anti-colonial self-determination movements around the world. ${ }^{100}$ Those peoples identify common experiences despite their unique and contextualised circumstances, and their voices pose a challenge to the restrictive interpretations of self-determination championed by dominant states.

\section{Contemporary Manifestations of Colonialism for Indigenous Peoples in Australia}

According to Thornberry, 'the history of indigenous peoples is a history of colonialism'. ${ }^{101}$ All Indigenous participants in this research identified a continuing colonial relationship between Indigenous peoples and the

O’Connor (2006).

O'Connor (2006).

Murphy (2006).

98 This is especially apparent currently in relation to the legal protection of the rights of Irish speakers in Northern Ireland. Anderson (2006).

100 For example, Burney (2006) and Maynard (2006).

101 Thornberry (1991), p 322. 
Australian state. In this regard, they echoed the famous comment on contemporary colonialism made by Yawuru elder and Aboriginal advocate Patrick Dodson in his influential Fourth Annual Vincent Lingiari Memorial Lecture of 1999. Dodson titled his lecture: 'Until the Chains are Broken: Aboriginal Unfinished Business'. ${ }^{102}$ The title was a reference to an excerpt from Frank Hardy's 1972 book The Unlucky Australians:

Will I, having written it, be free to turn to other books and obsessions, will you, having read it, be free to turn to the pursuit of happiness, will the lucky country remain free while the unlucky Australians are in chains? ${ }^{103}$

The colonial 'chains' that continue to bind Indigenous peoples in Australia, in Dodson's conception, are diverse; in all, he identified seventeen elements of 'Aboriginal unfinished business' that must be settled before the colonial legacy may be overcome. ${ }^{104}$ As was reflected in the responses from Indigenous participants in this research, contemporary colonialism in Australia goes beyond the historical theft of land and resources to encompass myriad continuing forms of domination and disempowerment. Here, I introduce three aspects of continuing colonial influence emphasised by Indigenous interviewees: the lack of recognition of Aboriginal sovereignty, the isolation of Indigenous people from governance, and cultural erasure and subjugation.

Even in the post-Mabo period, as Irene Watson stated, Australian legal and public institutions have failed to recognise or respect continuing Aboriginal sovereignty. ${ }^{105}$ The High Court has stated categorically that it has no jurisdiction to inquire into the acquisition of sovereignty by Britain in Australia, ${ }^{106}$ and consequently a native title regime has been developed that requires Indigenous claimants to establish an unbroken link between their 'traditional laws and customs', as practised at the time of European colonisation, and those laws and customs that they continue to practise today in connection with their traditional lands. ${ }^{107}$ Nor has the Australian Constitution developed to the point where it would drive, or at least facilitate, a fundamental alteration in the relationship between Aboriginal and Torres Strait Islander peoples and the Australian state. ${ }^{108}$

\footnotetext{
102 Dodson (2000), p 31.

103 Hardy (1968), p 249.

104 Dodson (2000).

105 Watson (2006).

106 Mabo v Queensland (No 2) (1992) 175 CLR 1.

107 Members of the Yorta Yorta Aboriginal Community v Victoria (2002) 194 ALR 538; Native Title Act 1993 (Cth), s 223.

108 Indigenous lawyer Larissa Behrendt argues that, even taking into account the 1967 referendum and consequential changes to the Constitution, in terms of the recognition of Indigenous sovereignty and rights, the Constitution has not moved far beyond the arrangements it set out when drafted in 1900: Behrendt (2006). In January 2012, the Expert Panel on the Constitutional Recognition of Indigenous Australians delivered a
} 
The absence of recognition of Indigenous sovereignty in the Australian legal and constitutional framework is hardly surprising, according to Linda Burney, considering that the prior occupation of Australia by Aboriginal and Torres Strait Islander people was not legally recognised until the Mabo decision of 1992. ${ }^{109}$ The framework of 'settlement' and 'terra nullius', which justified the colonisation of Australia in Anglo-Australian law, meant that the colonial relationship did not develop to the point reached in other comparable colonial states, such as Aotearoa/New Zealand, Canada and the United States, where prior Indigenous land ownership was acknowledged through treaties. ${ }^{110}$ Although Indigenous peoples in those states share experiences of colonisation and dispossession, the agreement of treaties has provided greater scope for the assertion of rights under domestic law than that afforded Indigenous peoples in Australia.

One of the key practical legacies of this failure to recognise Indigenous sovereignty has been the development of administrative frameworks that isolate and patronise Indigenous people in the present. This is evident in the lack of proportional representation of Indigenous people in important social institutions such as parliaments, the judiciary and the education system. Irabinna Rigney argued that this under-representation demonstrates the ongoing disproportion of power between Indigenous and non-Indigenous in Australia. ${ }^{111}$ Aden Ridgeway, the second Aboriginal person to be elected to the Commonwealth parliament, asserted that a consequence of this lack of representation is a governmental attitude that Aboriginal and Torres Strait Islander people remain, in a sense, 'wards of the state'. Ridgeway argued that this attitude results in a colonial governmental approach that emphasises Indigenous disadvantage, and suggests that governments are best placed to decide for Indigenous peoples how their circumstances might be improved. ${ }^{112}$ A parallel concern expressed by Mick Dodson is that the disempowerment of Indigenous people means that governments typically make decisions affecting Indigenous lives without seeking or gaining Indigenous consent. ${ }^{113}$ As is the case for Irish nationalists in the North of Ireland, Aboriginal and Torres Strait Islander peoples in Australia continue

report to the federal government, advocating constitutional amendment to recognise the distinctive status of Indigenous peoples and ensure that laws made specifically for them could only be made if they were beneficial: Expert Panel on Constitutional Recognition of Indigenous Australians (2012). It is as yet unclear how the government will respond to these recommendations.

109 Burney (2006).

110 Calma (2006). I do not claim here that Indigenous peoples in those states have entirely overcome colonisation, or that their land rights have been acknowledged adequately. However, the establishment of treaties with the colonising forces has provided some framework for the advancement of land and self-determination claims, and this framework remains absent in Australia.

111 Rigney (2006).

112 Ridgeway (2006).

113 Dodson (2006). 
to identify a colonial legacy in the marginalisation of their voices and ignorance about their concerns.

An abiding and unfortunate consequence of the marginalisation of Indigenous people from positions of influence in Australian society is the continued prevalence of racist and discriminatory attitudes towards Indigenous people. Larissa Behrendt asserted that Australia has not changed psychologically as a country, and that while the dominant community appears to resent public debates about racism or Indigenous rights, a key concern for many Indigenous people is bringing an end to the discrimination they routinely suffer. ${ }^{114}$ Arguably, one of the indicators of this abiding discrimination towards Indigenous people is the replacement and erasure of Indigenous cultures - for example, through the lack of provision for education in Indigenous languages. ${ }^{115}$ The problem of cultural erasure is emphasised as a key colonial barrier to Indigenous self-determination by Noel Pearson, who commented:

There's never been agreement by the country to say that Indigenous peoples are entitled to maintain their distinct identities, to maintain their languages, to maintain the integrity of their relationship with their traditional lands - we've not reached the point where those things have been proclaimed as foundations for moving forward. ${ }^{116}$

Encapsulated in Pearson's statement is the idea that colonialism abides wherever there is a failure to recognise and respect every people's equal right of self-determination.

\section{The Decolonisation of the International Law of Self- determination}

The international law of self-determination has been central to the project of decolonisation, which peaked in the 1960s and 1970s. If international law is to respond adequately to contemporary, anti-colonial self-determination claims, that law itself must be decolonised. In other words, the law must move beyond its almost exclusive association with ending a particular type of European colonialism, to develop a framework that can respond to the diverse self-determination claims of Indigenous peoples, nationalist groups, secessionists and devolutionists. ${ }^{117}$

Anti-colonial critiques of international law are the central project for the community of scholars known as Third World Approaches to International Law (TWAIL). Matua notes that these scholars seek to articulate 'an agenda for the reconstruction of international law through the TWAIL prism'. ${ }^{118}$ That is, international law as a system need not be

\footnotetext{
114 Behrendt (2006).

115 Rigney (2006).

116 Pearson (2006).

117 Simpson (1996), pp 256-57.

118 Matua (2000), p32.
} 
abandoned, but rather should be recast to allow for 'the full representivity of all voices, particularly those non-state, nongovernmental, rural and urban poor who constitute the majority in the Third World'. ${ }^{119}$ This article represents an attempt to provide a space for contemporary self-determination claimants - non-dominant voices in international legal discourse - to 'talk back' to international law. Due in part to its emphasis on 'universality', the human rights framework has been subject to the TWAIL critique that it helps to maintain a 'hegemonic international law'. ${ }^{120}$ Self-determination retains the capacity, however, to be continually asserted by Indigenous peoples and other marginalised communities of interest as a counter-hegemonic idea in international law. ${ }^{121}$

In this section, I consider three means by which the decolonisation of the law on self-determination may be achieved. First, analyses of international law should emphasise the various means by which the right of self-determination may manifest, in order to challenge statist assumptions that self-determination claims always threaten territorial integrity, and develop among states a willingness to reach negotiated solutions with claimant peoples. Second, and parallel to the first project, the artificial opposition between 'internal' and 'external' self-determination must be rejected, as it imposes a hierarchy on self-determination claims that leaves some claimant peoples marginalised from international legal dialogue. Finally, in order to enable claimant peoples to negotiate self-determination on equal terms with states and powerful international organisations, a more inclusive international legal system must be developed. I explore these proposals in the context of the Irish nationalist and Indigenous Australian case studies.

\section{The Decolonisation of International Law and the Irish Nationalist Claim}

There may be a contradiction at work between the international law on selfdetermination and the practice of the international community in relation to the right in recent times. Whereas the right is defined in broad terms, ${ }^{122}$ and various instruments confirm that it may take a range of forms subject to the will of the self-determining people, ${ }^{123}$ in practice there is resistance to changing borders. ${ }^{124}$ However, the Good Friday Agreement relieves international law of its usual concern for territorial integrity in the face of an

\footnotetext{
119 Matua (2000), p 37.

120 Rajagopal (2006), p 768.

121 Rajagopal (2006), p 770.

122 Common Article 1, International Covenant on Civil and Political Rights, opened for signature 16 December 1966, 999 UNTS 171 (entered into force 23 March 1976); International Covenant on Economic, Social and Cultural Rights, opened for signature 16 December 1966, 999 UNTS 3 (entered into force 3 January 1976).

$123 \quad$ Kirgis (1994), p 307.

124 O’Connor (2006).
} 
Irish nationalist self-determination claim. The Good Friday Agreement is a power-sharing agreement that established a devolved parliament in Northern Ireland, and marked a significant turning point in the Irish political conflict. The negotiating parties endorsed the decision of the British and Irish governments to:

(i) recognise the legitimacy of whatever choice is freely exercised by a majority of the people of Northern Ireland with regard to its status, whether they prefer to continue to support the Union with Great Britain or a sovereign united Ireland;

(ii) recognise that it is for the people of the island of Ireland alone, by agreement between the two parts respectively and without external impediment, to exercise their right of self-determination on the basis of consent, freely and concurrently given, North and South, to bring about a united Ireland, if that is their wish, accepting that this right must be achieved and exercised with and subject to the agreement and consent of a majority of the people of Northern Ireland ... ${ }^{125}$

On this basis, Ireland is one site in which the range of potentially legitimate manifestations of self-determination may be explored freely. International legal specialists may promote this exploration by drawing comparisons with the self-determination solutions developed elsewhere, by opening the international legal forum to the voices of Irish selfdetermination claimants and by promoting self-determination as a process rather than an event. In turn, by challenging the continuing reluctance within the international legal system to accept changes to borders as a consequence of the exercise of self-determination, ${ }^{126}$ the Irish case may assist the international legal system to develop more nuanced and sensitive approaches to the right. If it is effectively implemented, the Good Friday Agreement has the potential to become an example for the international community. Not only has the Agreement facilitated transition from violent conflict to negotiation, but it may in future enable a constitutional and territorial shift unfettered by the colonial doctrine of uti possidetis juris. ${ }^{127}$ This doctrine has caused ethnic conflict, ${ }^{128}$ encouraged separatist movements, compounded historical injustices and suppressed human rights. ${ }^{129}$

125 Agreement reached at multi-party negotiations, Belfast, 10 April 1998 (aka Good Friday Agreement or Belfast Agreement), 2. Constitutional Issues [1].

As is evidenced by the maintenance of the doctrine of uti possidetis juris.

This principle historically has required respect for the territorial status quo, such that newly formed states were constrained by established colonial borders: Frontier Dispute Case (Burkina Faso v Republic of Mali) ICJ Rep 1986, 554 at 556, Chamber of the International Court of Justice.

Ratner (1996), p 616. Ratner argues that the imposition of uti possidetis in former African, Yugoslav and Soviet states has caused ethnic conflict, rights violations and even genocide. Prescott and Triggs (2008), p 144. 
The international legal community ought also to discourage overly state-centred proposals in relation to self-determination. As McCorquodale recognises, states have typically opposed solutions that enable people to express multiple identities, or to be governed in more fluid ways to preserve the involvement of two interested states - for example, both Britain and Ireland in relation to Northern Ireland. ${ }^{130}$ In order to develop a peoplefocused and flexible self-determination solution in Ireland, all interested people must have an opportunity to contribute to an ongoing legal and political conversation. Indeed, several participants in this research argued that it is now time for such a discussion to begin, enabling all the people of the island to explore the range of possible options for their future. ${ }^{131}$ International law has a role in this discussion, as the framework capable of explaining and exploring the variety of legitimate manifestations of selfdetermination, and ensuring that any future solution reflects human rights principles.

To facilitate a discussion of the various means by which selfdetermination might be achieved in Ireland, it would be helpful to abandon the artificial distinction between 'internal' and 'external' self-determination. External self-determination denotes an exercise of the right that results in independent statehood, often through secession. Internal self-determination denotes the range of exercises of the right that may occur within the framework of an existing state. This distinction is irrelevant in Ireland as a consequence of the Good Friday Agreement provisions, which expressly permit a range of solutions, including the dissolution of the union with Britain and the unification of the Irish jurisdictions. Were the international legal framework to confirm that this distinction is unhelpful, through state practice and international legal commentary, this would be an important step in acknowledging the legitimacy of Irish nationalist experiences of colonialism and aspirations for self-determination. Rather than being limited by arbitrary categories that are not readily adaptable to each individual case, potential changes to territorial boundaries should be 'regulated in terms of an international society that is inclusive of all and allows all to find and use their voices within international society'. ${ }^{132}$ This development would meet the challenge from TWAIL scholars, who argue that all factors in international law that "maintain harmful hierarchies ... must be revisited and changed'. ${ }^{133}$

Ireland could also become an important site for the development of a more inclusive international legal system, in light of the Good Friday Agreement provisions that envisage novel self-determination solutions. As proposed by Robert McCorquodale, ${ }^{134}$ a system based on popular participation in international legal processes is an important step in

\footnotetext{
130 McCorquodale (2006).

131 Anderson (2006), McCorquodale (2006) and Ritchie (2005).

132 McCorquodale and Pangalangan (2001), p868.

133 Matua (2000), p38.

134 McCorquodale (2004).
} 
decolonising international law. The international legal forum could promote the implementation of the Good Friday Agreement by providing opportunities for the people of the island of Ireland to engage in their discussion of self-determination at the international level. This approach would accord with the formal legal recognition by Britain and Ireland that self-determination is an entitlement of the people of the island, rather than a privilege to be granted or withheld according to the whim of states. By opening this forum for such a discussion, the status of claimant peoples in relation to states could be enhanced. This would enable claimants to seek support for their proposals from other states and international organisations, and thereby to challenge the colonial hierarchy that still influences international power relations. A more inclusive international legal system could assist Irish self-determination claimants to overcome the history of British intransigence.

\section{The Decolonisation of International Law and Indigenous Claims in Australia}

The Good Friday Agreement nullified the consideration of territorial integrity in relation to a potential change of borders in Ireland. For that reason, the international legal system is obliged to consider the range of legitimate self-determination solutions available to the people of Ireland. In Australia, Indigenous self-determination claims will not result in changes to the state's territorial integrity. This fact removes the sting from Indigenous claims, and obliges international legal specialists to assist in the development of nuanced self-determination solutions. The Australian state has repeatedly demonstrated its unwillingness to understand selfdetermination as a right with a variety of legitimate manifestations, ${ }^{135}$ thus necessitating the deeper engagement of the international legal system to perform an educative and promotional role in relation to the right for Indigenous peoples.

As is clear in the concept of Aboriginal 'unfinished business', there are a number of context-appropriate means by which Aboriginal and Torres Strait Islander peoples may realise self-determination, without finding themselves constrained by statist notions of what is permitted by the artificial categories of internal and external self-determination. Concerns over territorial integrity must be abandoned, and the central connection

135 For example, when the Declaration on the Rights of Indigenous Peoples was adopted in 2007, Australia was only one of four states to refuse its consent. Government members at the time stated that the Declaration would provide 'rights to one group of Australians over all else' and that it 'could be misconstrued as conferring the right of secession upon indigenous peoples': ABC Radio (2010), quoting then Indigenous Affairs Minister Mal Brough, and Commonwealth Parliamentary Debates, Senate, 10 September 2007, p 62 (Mathias Cormann, Senator for Western Australia). Also, when the Aboriginal and Torres Strait Islander Commission was disbanded in 2004, then Indigenous Affairs Minister Amanda Vanstone likened the existence of parallel Indigenous and mainstream governance structures to a system of apartheid: Shaw (2004). 
between the significance of land to Indigenous peoples and selfdetermination must be honoured. ${ }^{136}$ Of parallel significance to land is sovereignty. The international legal system, and the Australian state, must broaden understandings of what sovereignty entails. ${ }^{137}$ Indeed,

the idea of nation states as islands of sovereignty no longer holds sway in a globalised and interdependent world. With some flexibility and imagination, Indigenous peoples' prior sovereignty could be recognised in a manner which enhances rather than fractures Australia's democratic system of governance. ${ }^{138}$

The notion of treaty is related to the concept of sovereignty. The existence of treaties between colonisers and colonised in other settler states, such as Aotearoa/New Zealand and Canada, has been credited with enhancing the degree of self-determination available to contemporary Indigenous claimants. ${ }^{139}$ In recent times, Indigenous peoples in Australia have advocated for a treaty or treaties with the state, as a means of establishing a new framework for relations. ${ }^{140}$ Governments have opposed such proposals on the basis that a treaty is an agreement between two sovereign entities. ${ }^{141}$ Respondents to this research argued in favour of a treaty or similar agreement, noting that the absence of such has diminished the status of Indigenous peoples since colonisation. ${ }^{142}$ The international legal system could provide a number of examples of treaties between colonising powers and Indigenous peoples, and provide a framework for the negotiation of contemporary treaties, informed by the extensive body of international human rights law.

As is the case for Irish nationalist claims to self-determination, the claims of Indigenous peoples in Australia could be promoted through the development of a more inclusive international legal system. Megan Davis noted that the non-binding Declaration on the Rights of Indigenous Peoples took more than 20 years to reach the adoption stage, and indicted the UN structure as insufficiently inclusive of non-state parties. ${ }^{143}$ The rights claims

136 Land is linked to self-determination for both Aboriginal traditional owners and urban Aborigines: Pearson (2006); Mundine and Valilis (2006).

137 Dodson (2006); Rigney (2006); Watson (2006); Yu (2006).

138 Behrendt et al (2009), p 19.

139 Thomas (1996), p 155. It is, however, important to note that conflicting interpretations of the Treaty of Waitangi have diminished its utility for Maori, who have a different understanding of its provisions on sovereignty than that promoted by the Crown: BuickConstable (2005), pp 120-21.

140 Hocking (2005), pp 267-68; Langton et al (2006); Moreton-Robinson (2005), p 70.

141 See, for example, a statement of former Prime Minister John Howard: 'A nation, an undivided united nation does not make a treaty with itself. I mean, to talk about one part of Australia making a treaty with another part is to accept that we are in effect two nations.' See Wright and Taylor (2000).

142 Calma (2006); Dodson (2006); Watson (2006).

143 Davis (2006). 
of Indigenous peoples raise the paradox of international law's incapacity to adequately realise a right accruing to an entity that is not recognised as having legal existence. ${ }^{144}$ In order to promote the value of participation, ${ }^{145}$ the international legal system could countenance a greater degree of status and standing for Indigenous peoples. As Noel Pearson stated, the development of 'an international apparatus for coexistence and reconciliation' between Indigenous peoples and states would facilitate creative self-determination solutions. ${ }^{146}$

A more inclusive system could be developed through increased acknowledgement of distinct Indigenous systems of law and custom. Irene Watson questioned why Aboriginal laws should generally be regarded as subordinate to the dominant Australian legal system. ${ }^{147}$ The international legal system could provide an example of the incorporation of Indigenous laws and ways of approaching problems, which could translate to more effective incorporation of Indigenous legal perspectives in domestic systems. Watson gave the examples of Aboriginal laws on environmental protection, land management and ecological sustainability as potentially valuable counterpoints to Western laws, some of which have enabled environmentally unsustainable development. ${ }^{148}$

It may also be necessary for the international community to develop its capacity to intervene constructively in the affairs of states, in order to overcome the paradox that the international community 'upholds the right to self-determination but can do so little to provide for its consistent or effective implementation'. ${ }^{149}$ As recent conflicts in Iraq and Palestine bear out, ${ }^{150}$ states can often choose whether, or at least to what extent, they will comply with international law. ${ }^{151}$ If international law is decolonised through the development of an inclusive legal system, Indigenous peoples and other minority groups will have a voice where they have previously struggled to be heard. They may be more successful in attracting advocates for their rights among the international community who are capable of applying political pressure to recalcitrant states. Mick Dodson argued in favour of such an approach, noting the disregard for international legal standards demonstrated by recent government approaches to Indigenous affairs, and stating that Australia must accept that the international community is meant to protect the interests of peoples as well as dominant states. ${ }^{152}$

\footnotetext{
144 Berman (1988-89), p 52.

145 McCorquodale (2004).

146 Pearson (2006).

147 Watson (2006).

148 Watson (2006).

$149 \quad$ Hurrell (2003), p 297.

150 Anderson (2006); Ritchie (2005).

151 Rigney (2006).

152 Dodson (2006)
} 
An inclusive international legal system would also assist Indigenous peoples to achieve self-determination by promoting connections between distant Indigenous representatives and enabling communication between communities. John Maynard suggested that if Indigenous peoples were better enabled to 'present a united front internationally', this would enhance their capacity to overcome domestic divisions caused by colonisation. ${ }^{153}$

\section{Conclusion}

Some contemporary self-determination claimant groups, including Irish nationalists in the North of Ireland and Indigenous peoples in Australia, can prove a continuing experience of colonialism. Their experiences demonstrate that the right retains a role in decolonisation, yet they do not conform to the archaic salt-water test of colonialism, making them 'hard cases' in international law. The international legal system risks failure on human rights grounds if it fails to acknowledge and address these contemporary, anti-colonial claims to self-determination. International law must serve justice and legitimacy for contemporary self-determination claimants, as it has sought to do for earlier claimants to the right. ${ }^{154}$ As Anghie has powerfully demonstrated, if international law is allowed to represent itself as having successfully reversed the effects of colonialism, the association between imperialism and international law becomes a feature of the past, rather than many peoples' present. ${ }^{155}$

The continuing colonial experiences of some contemporary selfdetermination claimants must be acknowledged in order to honour the equal entitlement of these claimants to self-determination. However, these peoples will only be empowered to realise self-determination when the international law regulating the right is itself decolonised. This mandates the recognition that self-determination may legitimately be exercised in a variety of ways, the rejection of the opposition between internal and external selfdetermination and the development of an inclusive international legal system.

Qualitative research is primarily concerned with credibility. Transferability is a principle more commonly associated with quantitative research. Yet it is possible for qualitative research to have transferable outcomes, and shed light on cases other than those under investigation. ${ }^{156}$ I have confined this research to the circumstances of two contemporary, anti-colonial claimant groups. However, my proposals for the decolonisation of international law can improve the way in which other contemporary assertions of the right are evaluated. Should contemporary self-determination claimants be empowered to take on greater

\footnotetext{
153 Maynard (2006).

154 While international law aims to create a degree of predictability through the promotion of norms, it must always strive to serve the interests of justice and legitimacy, particularly in relation to human rights: Ratner (1996), p 623.

155 Anghie (2006), p 740.

$156 \quad$ Baxter and Eyles (1997), p 515.
} 
status within the international legal system, their voices would challenge the typical statist position that self-determination claims pose unacceptable risks to state sovereignty or territorial integrity. The international legal system must require states to evaluate self-determination claims on their merits, thus enabling creative self-determination solutions in contemporary multi-ethnic states.

\section{References}

\section{Secondary Sources}

ABC Radio (2007) 'Indigenous Australians Treated as Equals, Says Brough', 15 September, www.abc.net.au/am/content/2007/s2033694.htm.

Aboriginal Provisional Government (1990) 'Towards Aboriginal Sovereignty', www.apg.org.au/files/towards.pdf.

S James Anaya (1993) 'A Contemporary Definition of the International Norm of Self-determination' 3 Transnational Law and Contemporary Problems 131.

Antony Anghie (2004) Imperialism, Sovereignty and the Making of International Law, Cambridge University Press.

Antony Anghie (2006) 'The Evolution of International Law: Colonial and Postcolonial Realities' 27 Third World Quarterly 739.

Bill Ashcroft, Gareth Griffiths and Helen Tiffin (eds) (1995) The Post-colonial Studies Reader, Routledge.

Bill Ashcroft, Gareth Griffiths and Helen Tiffin (eds) (2000) Post-Colonial Studies: The Key Concepts, Routledge.

Jamie Baxter and John Eyles (1997) 'Evaluating Qualitative Research in Social Geography: Establishing "Rigour" in Interview Analysis' 22 Transactions of the Institute of British Geographers 505.

Larissa Behrendt, Chris Cunneen and Terri Libesman (2009) Indigenous Legal Relations in Australia, Oxford University Press.

Christine Bell and Kathleen Cavanaugh (1998-99) 'Self-determination, Group Accommodation, and the Belfast Agreement' 22 Fordham International Law Journal 1345.

Nathaniel Berman (1988-89) 'Sovereignty in Abeyance: Self-determination and International Law' 7 Wisconsin International Law Journal 51.

Stuart Bradfield (2006) 'Separatism or Status-Quo? Indigenous Affairs from the Birth of Land Rights to the Death of ATSIC' 52 Australian Journal of Politics and History 80.

Ian Brownlie (2003) Principles of Public International Law, Oxford University Press.

John Buick-Constable (2005) 'Indigenous-State Relations in Aotearoa/New Zealand: A Contractual Approach to Self-determination', in Barbara A Hocking (ed), Unfinished Constitutional Business? Rethinking Indigenous Self-determination, Aboriginal Studies Press.

Michelle Byrne (2001) 'Grounded Theory as a Qualitative Research Methodology' 73 Association of Operating Room Nurses Journal 1155.

Antonio Cassese (2nd ed) (2005) International Law, Oxford University Press.

Pamela Clayton (1996) Enemies and Passing Friends: Settler Ideologies in Twentieth Century Ulster, Pluto Press.

Tim Pat Coogan (2003) Ireland in the Twentieth Century, Arrow Books.

Annie E Coombes (ed) (2006) Rethinking Settler Colonialism: History and Memory in Australia, Canada, Aotearoa New Zealand and South Africa, Manchester University Press. 
Erica-Irene A Daes (1993) 'Some Considerations on the Right of Indigenous Peoples to Selfdetermination' 3 Transnational Law and Contemporary Problems 1

Department of Foreign Affairs and Trade (2009) Kosovo: Country Brief, www.dfat.gov.au/geo/kosovo/country_brief.html.

Martin Dixon and Robert McCorquodale (2003) Cases and Materials on International Law, 4th edn, Oxford University Press.

Patrick Dodson (2000) 'Until the Chains are Broken: Aboriginal Unfinished Business' 45 Arena 29.

Expert Panel on Constitutional Recognition of Indigenous Australians (2012) 'Recognising Aboriginal and Torres Strait Islander Peoples in the Constitution', Commonwealth Government.

Frantz Fanon (1965) The Wretched of the Earth, MacGibbon and Kee.

Michael Farrell (1980) Northern Ireland: The Orange State, 2nd edn, Pluto Press.

Barney Glaser and Anselm Strauss (1967) The Discovery of Grounded Theory: Strategies for Qualitative Research, Aldine.

Hécor Gros Espiell (1980) 'The Right to Self-determination: Implementation of United Nations Resolutions' (E/CN.4/Sub.2/405), United Nations.

Hurst Hannum (1993-94) 'Rethinking Self-determination' 34 Virginia Journal of International Law 1.

Frank Hardy (1968) The Unlucky Australians, One Day Hill.

Beth Harry, Keith M Sturges and Janette K Klingner (2005) 'Mapping the Process: An Exemplar of Process and Challenge in Grounded Theory Analysis' 34(2) Educational Researcher 3.

Barbara A Hocking (2005) 'Commenced Constitutional Business? Reflections on the Contribution of the Saami Parliaments to Indigenous Self-Determination', in Barbara A Hocking (ed), Unfinished Constitutional Business? Rethinking Indigenous Self-Determination, Aboriginal Studies Press.

Andrew Hurrell (2003) 'International Law and the Making and Unmaking of Boundaries', in Allen E Buchanan and Margaret Moore (eds), States, Nations and Borders: The Ethics of Making Boundaries, Cambridge University Press.

R Burke Johnson (1997) 'Examining the Validity Structure of Qualitative Research' 118(2) Education 282.

Frederic L Kirgis, Jr (1994) 'The Degrees of Self-determination in the United Nations Era' 88 American Journal of International Law 304.

Eric Kolodner (1994-95) 'The Future of the Right of Self-determination' 10 Connecticut Journal of International Law 153.

Marcia Langton, Odette Mazel, Lisa Palmer, Kathryn Shain and Maureen Tehan (eds) (2006) Settling With Indigenous People, Federation Press.

Ralph LaRossa (2006) 'Grounded Theory Methods and Qualitative Family Research' 67 Journal of Marriage and Family 837.

Ann Chih Lin (1998) 'Building Positivist and Interpretivist Approaches to Qualitative Methods' 26 Policy Studies Journal 162.

Ania Loomba (2005) Colonialism/Postcolonialism, 2nd edn, Routledge.

Michael Mansell (2003) 'The Decline of the Aboriginal Protest Movement' Green Left, 27 August, www.greenleft.org.au/node/29182.

Michael Mansell (2005) 'Why Norfolk Island but Not Aborigines?' in Barbara A Hocking (ed), Unfinished Constitutional Business? Rethinking Indigenous Self-Determination, Aboriginal Studies Press.

Makau Matua (2000) 'What is TWAIL?' 94 American Society of International Law Proceedings 31.

Robert McCorquodale (1992) 'Self-determination Beyond the Colonial Context and its Potential Impact on Africa' 4 Revue Africaine de Droit International et Comparé 592. 
Robert McCorquodale (2004) 'An Inclusive International Legal System' 17 Leiden Journal of International Law 477.

Robert McCorquodale and Raul Pangalangan (2001) 'Pushing Back the Limitations of Territorial Boundaries' 12 European Journal of International Law 867.

Aileen Moreton-Robinson (2005) 'Patriarchal Whiteness, Self-Determination and Indigenous Women: The Invisibility of Structural Privilege and the Visibility of Oppression', in Barbara A Hocking (ed), Unfinished Constitutional Business? Rethinking Indigenous Self-Determination, Aboriginal Studies Press.

Garth Nettheim (1988) “Peoples" and "Populations": Indigenous Peoples and the Rights of Peoples', in James Crawford (ed), The Rights of Peoples, Oxford University Press.

Kwame Nkrumah (1965) Neo-colonialism: The Last Stage of Imperialism, Nelson.

Noel Pearson (2006) 'Uses of Layered Identities', The Australian, 18-19 November.

John Robert Victor Prescott and Gillian D Triggs (2008) International Frontiers and Boundaries: Law, Politics and Geography, Martinus Nijhoff.

Balakrishnan Rajagopal (2006) 'Counter-hegemonic International Law: Rethinking Human Rights and Development as a Third World Strategy' 27 Third World Quarterly 767.

Steven R Ratner (1996) 'Drawing a Better Line: Uti Possidetis and the Borders of New States' 90 American Journal of International Law 590.

J Atticus Ryan and Christopher A Mullen (1998) Unrepresented Nations and Peoples Organization: Yearbook, Kluwer Law International.

Jean-Paul Sartre (1964) Colonialism and Neocolonialism, Routledge.

Meaghan Shaw (2004) 'Vanstone Enrages Black Leaders', The Age, 17 April, www.theage.com.au/articles/2004/04/16/1082055648728.html.

Gerry J Simpson (1996) 'The Diffusion of Sovereignty: Self-determination in the Post-Colonial Age' 32 Stanford Journal of International Law 255.

Anselm Strauss and Juliet Corbin (1998) Basics of Qualitative Research: Techniques and Procedures for Developing Grounded Theory, Sage.

Roy Suddaby (2006) 'From the Editors: What Grounded Theory is Not' 49(4) Academy of Management Journal 633.

George Steven Swan (1986) 'Irish Unification as Northern Ireland Self-determination: A Speculative Reappraisal of the Evidence' 2 Florida International Law Journal 129.

Nin Thomas (1996) 'Te Reo Maori - Te Reo Rangatira o Aotearoa - Te Okeoke Roa - The Maori Language - The Chiefly Language of Aotearoa - The Long Struggle', in Greta Bird, Gary Martin and Jennifer Nielsen (eds), Majah: Indigenous Peoples and the Law, Federation Press.

Patrick Thornberry (1989) 'Self-determination, Minorities, Human Rights: A Review of International Instruments' 28 International and Comparative Law Quarterly 867.

Patrick Thornberry (1991) International Law and the Rights of Minorities, Clarendon Press.

Gillian D Triggs (2006) International Law: Contemporary Principles and Practices, LexisNexis Butterworths.

United Nations Mission in Kosovo (2007) Comprehensive Proposal for the Kosovo Status Settlement, UN.

D van Arkel and Robert Ross (eds) (1982) Racism and Colonialism: Essays on Ideology and Social Structure, Martinus Nijhoff.

David Wippman (1998) 'Introduction: Ethnic Claims and International Law', in David Wippman (ed), International Law and Ethnic Conflict, Cornell University Press.

Tony Wright and Kerry Taylor (2000) 'PM Rules Out Divisive Treaty', The Age, 30 May. 


\section{Interviews}

Martina Anderson, interview recorded in Belfast, 21 March 2006. Martina Anderson is an Irish nationalist politician, sitting in the Northern Ireland Assembly for Sinn Féin, and a former IRA Volunteer and prisoner.

Larissa Behrendt, interview recorded in Sydney, 8 September 2006. Larissa Behrendt is a Eualeyai and Kamillaroi woman and a Professor of Law.

Christine Bell, interview recorded in Derry, 27 October 2005. Christine Bell is a Professor of Law and a specialist in transitional justice.

Linda Burney, interview recorded in Sydney, 15 November 2006. Linda Burney is a Wiradjuri woman, Labor politician and MLA in New South Wales.

Tom Calma, interview recorded in Sydney, 11 December 2006. Tom Calma is a Kungarakan elder and a member of the Iwaidja tribal group, a long-time public servant and former Aboriginal and Torres Strait Islander Social Justice Commissioner.

Anthony Coughlan, interview recorded in Dublin, 3 March 2006. Anthony Coughlan is an Irish academic, and a commentator on Irish engagement with Europe.

Megan Davis, interview recorded in Sydney, 5 December 2006. Megan Davis is of Cobble Cobble/Waka Waka Aboriginal heritage and South Sea Island descent, and is a Professor and practitioner of law. In 2010, Davis was elected as an Expert Member of the UN Permanent Forum on Indigenous Issues.

Mick Dodson, interview recorded in Canberra, 22 September 2006. Mick Dodson is a Yawuru man, Professor of Law and former member of the UN Permanent Forum on Indigenous Issues.

Terry Enright, interview recorded in Belfast, 2 February 2006. The late Terry Enright was a member of the Irish nationalist community in Belfast, and a long-time community worker and human rights activist.

Paul Hughes, interview recorded in Adelaide, 29 August 2006. Paul Hughes is a former public servant and Aboriginal educationalist. He is a Yunkunyatjatjara/ Narunnga/Kaurna man.

John Maynard, interview recorded in Newcastle, 9 November 2006. John Maynard is a Worimi man and a Professor of History.

Bernadette McAliskey, interview recorded in Dungannon, 7 June 2006. Bernadette McAliskey is an Irish republican and socialist activist, and a former politician, who continued to contribute to public debate on the Irish national question and directs the South Tyrone Empowerment Program, supporting migrant workers.

Robert McCorquodale, interview recorded in Nottingham, 27 March 2006. Robert McCorquodale is a Professor and practitioner of international law.

Mick Mundine and Peter Valilis, interview recorded in Sydney, 8 August 2006. Mick Mundine is a community leader in Australia's most prominent urban Aboriginal community, Redfern in Sydney. Mundine and Peter Valilis were office-holders in the Aboriginal Housing Company at the time of our interview.

Niall Murphy, interview recorded in Belfast, 15 March 2006. Niall Murphy is a member of the Irish nationalist community, and a legal practitioner in Belfast.

Eoin Ó Broin, interview recorded in Belfast, 24 January 2006. Eoin Ó Broin is an Irish nationalist political activist, Sinn Féin politician and writer.

Paul O'Connor, interview recorded in Derry, 2 March 2006. Paul O'Connor is an Irish nationalist human rights activist, based at the Pat Finucane Centre in Derry, which represents the families of victims of conflict in their efforts to gain justice and truth. 
Noel Pearson, interview recorded in Cairns, 6 December 2006. Noel Pearson is a member of the Bagaarrmugu and Guggu Yalanji peoples, a lawyer and community representative of Cape York Indigenous communities.

Aden Ridgeway, interview recorded in Sydney, 28 November 2006. Aden Ridgeway is a Gumbayyngirr man, a former federal politician and a public servant, and is active in a wide range of public policy areas.

Irabinna Rigney, interview recorded in Adelaide, 29 August 2006. Irabinna Rigney is an Aboriginal educationalist, academic and a member of the Narungga, Ngarrindjeri, Andyamathanha and Kaurna language groups.

Mike Ritchie, interview recorded in Belfast, 7 December 2005. Mike Ritchie is a community worker who represents former Irish republican political prisoners.

Bríd Rodgers, interview recorded in Lurgan, 9 March 2006. Bríd Rodgers is a former Irish nationalist politician and founding activist in the civil rights movement.

Margaret Ward, interview recorded in Belfast, 19 January 2006. Margaret Ward is an Irish historian and human rights activist, and Director of the Women's Research and Development Agency, an organisation situated in Belfast and dedicated to the promotion of women's equality and rights.

Irene Watson, interview recorded in Adelaide, 30 August 2006. Irene Watson is a member of the Tanganekald and Meintangk peoples, a legal practitioner and academic, and former member of the UN Working Group on Indigenous Populations.

Peter Yu, interview recorded in Sydney, 29 September 2006. Peter Yu is a Yawuru man and prominent Indigenous community activist, particularly in the area of land rights. He is a former chairman of the Kimberley Land Council.

\section{International Agreements and Parliamentary Documents}

Agreement reached at multi-party negotiations, Belfast, 10 April 1998 (aka Good Friday Agreement or Belfast Agreement).

Commonwealth, Parliamentary Debates, Senate, 10 September 2007, p 62 (Mathias Cormann, Senator for Western Australia).

Frontier Dispute Case (Burkina Faso v Republic of Mali) ICJ Rep 1986, 554 at 556, Chamber of the International Court of Justice.

Independence of Namibia (1978) SC Res 435, 33 UN SCOR, 2087th mtg, UN Doc S/12865.

International Covenant on Civil and Political Rights, opened for signature 16 December 1966, 999 UNTS 171 (entered into force 23 March 1976).

International Covenant on Economic, Social and Cultural Rights, opened for signature 16 December 1966, 999 UNTS 3 (entered into force 3 January 1976).

Resolution on East Timorese Self-determination (1975) SC Res 384, 1869th mtg

Treaty on the Final Settlement with Respect to Germany (1990) 29 ILM 1187 (signed 12 September 1990)

\section{Cases}

Mabo v Queensland (No 2) (1992) 175 CLR 1

Members of the Yorta Yorta Aboriginal Community v Victoria (2002) 194 ALR 538

\section{Legislation}

Native Title Act 1993 (Cth) 